\title{
PERAN PEMBIMBING DALAM MENGATASI PERKEMBANGAN KOGNITIF STUDI KASUS DI UPT. PANTI SOSIAL PENGASUHAN ANAK
}

\section{Oleh: Rahmalina ${ }^{1}$, Azni $^{2}$ \\ 1,2 UIN Suska Riau \\ Email. amarahma525@gmail.com}

Abstract: Pemberian bimbingan ini bisa melaui orang tua, guru ataupun lembaga lainnya. Namun tidak semua anak yang terlahir didunia ini mendapatkan asuhan yang sempurna oleh kedua orang tuanya, mungkin karena sebab kematian, ataupun karena faktor ekonomi sehingga menjadikan panti asuhan sebagai tempat dimana mereka bisa bertahan hidup. Anak Tunas Bangsa, Panti yang bermasalah pada awal tahun 2017. Yang mana seluruh anak Panti Tunas Bangsa pada waktu itu dibawa dan ditampung Di Panti Asuhan Sosial pengasuhan anak milik Dinas Sosial Provinsi. Penelitian ini bertujuan untuk mengetahui bagaimana Peran Pembimbing Dalam Mengatasi Perkembangan Kognitif Studi Kasus di UPT. Panti Sosial Pengasuhan Anak Dinas Sosial Provinsi Riau. Motode yang digunakan adalah deskriptif kualitatif yaitu setelah data terkumpul selanjutnya adalah penganalisaan data yang telah ada, dan teknik pengumpulan data yang digunakan penulis adalah wawancara, observasi dan dokumentasi. Yang menjadi subjek dalam penelitian ini adalah pembimbing panti asuhan sebanyak 2 orang dan yang menjadi objek penelitian ini adalah Peran Pembimbing Dalam Mengatasi Perkembangan Kognitif Studi Kasus di UPT. Panti Sosial Pengasuhan Anak Dinas Sosial Provinsi Riau. Hasil dari penelitian ini menunjukan bahwa Peran Pembimbing Dalam Mengatasi Perkembangan Kognitif Studi Kasus di UPT. Panti Sosial Pengasuhan Anak Dinas Sosial Provinsi Riau adalah pembimbing sebagai pamong belajar, sebagai penyuluh, sebagai fasilitator, sebagai tutor sangat membantu dalam mengatasi permasalahan kognitif pada anak asuh, dilihat dari hasil wawancara terhadap pembimbing mengatakan bahwa peran pembimbing dalam mengatasi perkembangan kognitif anak asuh telah terlaksana dengan baik, walaupun dalam membimbing dan mendidik adanya hambatan.

Kata Kunci: Peran Pembimbing, Perkembangan, Kognitif 


\section{PERAN PEMBIMBING DALAM MENGATASI PERKEMBANGAN KOGNITIF STUDI KASUS DI UPT. PANTI SOSIAL PENGASUHAN ANAK}

\section{Oleh: Rahmalina ${ }^{1}$, Azni $^{2}$ 1,2 UIN Suska Riau \\ Email.amarahma525@gmail.com}

\section{Pendahuluan}

Salah satu fenomena isu penting adalah munculnya model "politik dinasti" yang merupakan salah satu bentuk kekuasaan politik yang dijalankan oleh sekelompok orang yang masih terkait dalam hubungan keluarga dan "dinasti politik" yang lebih indentik dengan kerajaan, di mana kekuasaan raja akan diwariskan secara turun temurun dari ayah kepada anak cucu agar kekuasaan akan tetap berada di lingkaran keluarga ${ }^{1}$. Para politikus lebih suka mewariskan kekuasaan kepada kerabatnya, yang diyakini akan lebih loyal dan tidak akan berkhianat, dengan cara memanipulasi sistem politik dan demokras².

Beraneka ragam perilaku manusia membuat sulit untuk bisa memahaminya. Dalam masa pembentukan perilaku dan perkembangan pola pikir anak, pemberian bimbingan sangat diperlukan ${ }^{3}$. Pemberian bimbingan ini bisa melaui orang tua, guru ataupun lembaga lainnya ${ }^{4}$. Namun tidak semua anak yang terlahir didunia ini mendapatkan asuhan yang sempurna oleh kedua orang tuanya, mungkin karena sebab kematian, ataupun karena faktor ek onomi sehingga menjadikan Panti

\footnotetext{
${ }^{1}$ Santi Anjarsari and Sri Hartini, 'Upaya Pengelola Program Penguatan Keluarga SOS Children's Villages Indonesia Dalam Mengurangi Jumlah Anak-Anak Yang Rentan Terlantar', Comm-Edu (Community Education Journal), 1.1 (2018), 38-44; Anissa Nur Fitri, Agus Wahyudi Riana, and Muhammad Fedryansyah, 'Perlindungan Hak-Hak Anak Dalam Upaya Peningkatan Kesejahteraan Anak', Prosiding Penelitian Dan Pengabdian Kepada Masyarakat, 2.1 (2015). ${ }^{2}$ Anggraini Merry, Asrinaldi Asrinaldi, and Aidinil Zetra Zetra, 'PENGARUH KESADARAN DAN KEPERCAYAAN POLITIK TERHADAP PARTISIPASI POLITIK MASYARAKAT DHARMASRAYA PADA PILKADA 2015', Madania: Jurnal Ilmu-Ilmu Keislaman, 8.1 (2018), 109-32.

${ }^{3}$ LINDA KHUSNUL QOTIMAH, 'PENGELOLAAN PANTI ASUHAN AL-RIFDAH SEMARANG DALAM PEMENUHAN HAK ANAK' (Universitas Negeri Semarang, 2015).

${ }^{4}$ QOTIMAH.
} 
asuhan sebagai tempat dimana mereka bisa bertahan hidup ${ }^{5}$.

Salah satu upaya memberikan perlindungan kepada anak-anak terlantar maka Di Pekanbaru menyediakan UPT. Panti Sosial Pengasuhan Anak Dinas Sosial Provinsi Riau Pekanbaru yang terletak di JIn. Dr. Sutomo. UPT. Panti Sosial Pengasuhan Anak ini merupakan Panti Asuhan yang dibangun pemerintah Pekanbaru dibawah naungan Dinas Sosial Pekanbaru yang diperuntukkan untuk anak dari keluarga kurang mampu, terlantar. Anak- anak yang berada Di Panti sosial pengasuhan anak umumnya sudah lepas asuh dari orang tuanya, dan mereka ditampung untuk mendapatkan pengasuhan yang lebih layak.

Kasus meninggalnya anak balita M. Zikli, 18 bulan di Panti Asuhan Tunas Bangsa Pekanbaru Riau menyeret sang pemilik, Hj Lili Rahmawati. Perempuan yang dikenal sebagai ratu Panti Sosial itu ditetapkan sebagai tersangka kasus tersebut.

$\mathrm{Hj}$ Lili Rahmawati memiliki lima Panti sayangnya kondisi lima Panti itu sangat meprihatinkan. Panti pertama terletak di Jalan Bukit Raya, Pekanbaru. Disanalah awal mula Lili menapak karir sebagai pekerja sosial. Di panti itu juga balita Zikli diasuh sebelum akhirnya meninggal.

Tak jauh dari Panti pertama, Lili mendirikan Panti kedua. Bangunannya dua lantai dengan cat kuning hijau. Kondisi bangunan tersebut sama dengan seluruh Panti milik Lili, yakni tidak terawat dan terkesan kumuh. Banyak barang yang berserakan. Kaca jendela dibiarkan pecah di sana-sini. Penghuninya dimasukkan di ruangan dengan pintu dan terali besi mirip penjara.

\section{Metodologi Penelitian}

Dari riset yang diajukan ke UPT. Panti Sosial Pengasuh Anak Pekanbaru memberikan jangka Waktu penelitian yakni pada tanggal 15 Februari 2019, dan batas waktu penelitian berakhir pada tanggal 15 April 2019. Setelah batas waktu yang telah ditentukan itu habis, maka penelitian juga selesai, apabila dalam penelitian belum selesai maka dilakukan kembali surat riset penelitian. Keterangan: Dari table diatas, peneliti akan menjelaskan bahwa peneliti melakukan penelitian selama enam bulan pada tahun dua ribu delapan belan dan dua ribu Sembilan

\footnotetext{
${ }^{5}$ Wasisto Raharjo Djati, 'Revivalisme Kekuatan Familisme Dalam Demokrasi: Dinasti Politik Di Aras Lokal', MASYARAKAT: Jurnal Sosiologi, 2015 <https://doi.org/10.7454/mjs.v18i2.3726>.
} 
belas yang telah diuraikan pada table diatas.

Penelitian ini dilakukan Di UPT. Panti Pengasuh Anak milik Dinas Sosial Provinsi Pekanbaru yang beralamat JI.Dr. Sutomo, Suka Mulia, Sail, Kota Pekanbaru 28156. Pemilihan lokasi ini didasari atas pertimbangan bahwa persoalan-persoalan yang diteliti ada dilokasi ini.

\section{Hasil dan Pembahasan}

Tepat pada tanggal 29 Januari 2017 Kasus meninggalnya anak balita M. Zikli, 18 bulan, di Panti Asuhan Tunas Bangsa Pekanbaru, Riau, menyeret sang pemilik, $\mathrm{Hj}$ Lili Rachmawati. Perempuan yang dikenal sebagai ratu panti sosial itu ditetapkan sebagai tersangka kasus tersebut. ${ }^{6}$

Kemudian sebanyak 17 anak Tunas Bangsa diletakkan di Panti Sosial pengasuhan anak milik Dinas Sosial Provinsi Pekanbaru. 10 dari 17 anak Tunas Bangsa belum bisa membaca dikarenakan selama mereka berada Dipanti Tunas Bangsa tidak disekolahkan oleh ibu Hj Lili Rachmawati. Hanya ada satu orang anak saja yang disekolahkan ibu lili ini.

Hasil penelitian berikut berdasarkan penelitian yang dilaksanakan di UPT. Panti sosial pengasuhan anak Dinas sosial. Penelitian ini bertujuan untuk mendapatkan tentang bagaimana "Peran Pembimbing Dalam Mengatasi Perkembangan Kognitif Studi Kasus Di UPT. Panti Sosial Pengasuhan Anak Dinas Sosial Provinsi Riau.". Untuk itu teknik pengumpulan data sesuai dengan apa yang telah dikemukakan pada bab tiga. Metode penelitian yaitu dengan menggunakan wawancara, observasi dan dokumentasi.

Wawancara dilakukan dengan mengajukan beberapa pertanyaan kepada satu orang pekerja sosial (peksos) dan satu orang pengasuh, dengan ini penulis mengadakan pengamatan langsung (observasi) dengan tujuan untuk lebih mengetahui keadaan yang sesungguhnya yang terjadi dilapangan.

Untuk mengetahui bagaimana Peran Pembimbing Dalam Mengatasi Perkembangan Kognitif Studi Kasus Di UPT. Panti Sosial Pengasuhan Anak Dinas Sosial Provinsi Riau maka penulis mengajukan delapan pertanyaan secara langsung kepada informan guna mendapatkan data. Berikut adalah hasil wawancara yang telah peneliti

6 'Kasus-Panti-Asuhan-Polisi-Temukan -12-Anak-Dipersembunyian’. 
dapat dari Ibu Wati dan Ibu Shinta selaku Pembimbing yang telah peneliti dapatkan di UPT. Panti Sosial Pekanbaru:

1. Cara melakukan pendekatan pada anak-anak?

Ibu Wati: bunda mengatakan untuk melakukan pendekatan dengan anak-anak yaitu dengan rasakan anak yang kita asuh seperti anak kita sendiri, kemudian kita analisa karakter anak tersebut dan pahami apa keinginan anak asuh.

Ibu Sinta: menganggap bahwa anak yang kita asuh seperti anak sendiri, seperti adik sendiri keuarga sendiri dan kita bertanggung jawab atas mereka.

Dapat disimpulkan berdasarkan hasil wawancara dengan kedua pembimbing maka dapat disimpulkan bahwa melakukan pendekatan pada anak asuh adalah dengan menganggap mereka seperti keluarga sendiri.

2. Cara membangun hubungan dengan anak-anak sehingga mereka mulai terbuka?

Ibu Wati: bunda mengatakan seringnya melakukan komunikasi kepada anak, supaya anak mulai terbiasa dan sering bertanya apa yang mereka inginkan.

Ibu Sinta: terus melakukan komunikasi, face to face agar anak asuh tidak canggung kemudian bisa terbuka.

Dapat disimpulkan berdasarkan hasil wawancara dengan kedua pembimbing maka dapat disimpulkan bahwa adanya melakukan terus menerus komunikasi antara pembimbing dan anak asuh. Agar anak asuh mudah untuk terbuka.

3. Nasihat atau bantuan apa yang diberikan sehingga anak dapat merubah perilaku yang baik untuk dimasa yang akan datang?

Ibu Wati: sering membawa mereka kearah kebaikan sehingga mereka bisa membedakan perilaku yang baik dan buruk seperti apa. Selalu memberikan contoh baik bagaimana seharusnya kita berperilaku.

Ibu Sinta: mengajarkan anak tentang kebaikan sehingga ana mengerti mana yang sebaiknya anak mengerti mana yang sebaiknya dilakukan dan yang mana tidak boleh dilakukan. Serta memberikan contoh yang baik pada anak.

Dapat disimpulkan berdasarkan hasil wawancara dengan kedua pembimbing memberikan contoh yang baik pada anak asuh baik itu secara lisan dan perbuatan, supaya anak asuh dapat meniru. 
4. Kendala-kendala yang dihadapi selama memberikan bimbingan kepada anak-anak?

Ibu Wati: Sangat banyak karena anak asuh kita sudah dari awal terbentuk dibentuk jadi anak yang berkepribadian tidak baik dibawah rata-rata seperti diajarkan menjadi pengemis.

Ibu Sinta: Banyak kendala, karena sudah salah poa asuh mereka dari pengasuh yang lama ya selama di Tunas Bangsa.

Dapat disimpulkan berdasarkan hasil wawancara dengan kedua pembimbing banyaknya kendala karena dari awal anak asuh sudah diasuh dengan pola yang salah.

5. Peran dalam mengatasi perkembangan kognitif bermasalah pada anak asuh?

Ibu Wati: selalu berusaha yang terbaik untuk anak bersifat tegas dan selalu menyongkong atau support minat mereka.

Ibu Sinta: diwaktu senggang kadang menyempatkan untuk mengajarkan mereka seperti membaca, membantu mengeja huruf demi huruf kalimat demi kalimat.

Dapat disimpulkan berdasarkan hasil wawancara dengan kedua pembimbing berusaha membantu dan memsupport minat belajar anak asuh.

6. Adakah program-program untuk membantu memperbaiki perkembangan kognitif bermasalah anak asuh?

Ibu Wati: ada, memberikan bimbingan kerohanian, ekstrakulikuler belajar memasak. Bunda mengatakan adanya program baru yang mana

setiap hari kamis dan jum'at siang, anak asuh diajarkan memasak dan membuat kerajinan. Guna untuk bekal mereka dimasa akan datang. Ibu Sinta: banyak program kita, memberikan beberapa bimbingan, seperti bimbingan belajar, bimbingan ekstrakulikuler, bimbingan rohani, belajar jahit untuk yang sudah SMP sama SMA ya.

Dapat disimpulkan berdasarkan hasil wawancara dengan kedua pembimbing adanya bimbingan belajar, bimbingan ekstrakulikuler, bimbingan rohani, bimbingan mental.

7. Sejauh mana keberhasilan kegiatan yang dilaksanakan untuk membantu mengatasi kognitif bermasalah pada anak asuh? Ibu Wati: sudah lebih kurang $75 \%$ lebih bagus dari sebelumnya. Ibu Sinta: sudah sekitar 75\% lebih baik dari yang sebelumnya. 
Dapat disimpulkan berdasarkan hasil wawancara dengan kedua pembimbing sudah $75 \%$ anak asuh lebih baik dari yang awal. 8. Adakah faktor penyebab anak asuh sulit membaca?

Ibu Wati : anak-anak sulit mengenali huruf demi huruf, susah dalam membedakan huruf.

Ibu Sinta : tidak adanya kemauan atau keinginan untuk membaca, susah untuk mengenali.

Dapat disimpulkan berdasarkan hasil wawancara bahwa faktor anak sulit membaca adalah anak sulit membedakan huruf demi huruf seperti D diucapkan B.

9. Apa saja peran Ibu selaku pembimbing anak asuh di Panti ini?

Ibu Wati : menjadi pamong belajar untuk anak, sebagai penyuluh, sebagai fasilitator untuk anak, menjadi tutor untuk anak.

Ibu Sinta : menjadi Pamong untuk anak, memfasilitasi anak, memberkan penyuluhan, dan menjadi tutor.

Dapat disimpulkan bahwa peran pembimbing adalah pembimbing sebagai pamong belajar untuk anak, sebagai penyuluh, sebagai fasilitator, sebagai tutor.

10. Adakah perencanaan lbu di Panti ini sebagai seorang pembimbing? Membuat persiapan atau membuat rencana pelayanan, semacam persiapan tertulis tentang pelayanan yang akan dilaksankan.

11.Pelaksanaan yang seperti apa yang ibu buat untuk anak asuh?

Pelaksanaan kegiatan layanan harus disesuaikan dengan perencanaan, seperti diadakannya bimbingan belajar, bimbingan ekstrakulikuler, bimbingan agama dan bimbingan mental.

12. Bagaimana proses evaluasi yang ibu lakukan?

Evaluasi merupakan kegiatan menilai keberhasilan layanan dalam bidang bimbingan belajar, bimbingan ekstrakulikuler, bimbinga agama dan bimbingan mental. Prosesnya setelah diterapkan nya pelaksanaan kegiatan-kegiatan lalu kita lakukan evaluasi, memberikan tugas-tugas kepada anak asuh ujian atau praktekpraktek.

13. Proses penganalisisan yang ibu lakukan?

Setelah dilakukan evaluasi hasil dari evaluasi perlu untuk dianalisis untuk mengetahui seluk beluk kemajuan dan perkembangan yang diperoleh oleh anak asuh.

Adapun program kegiatan dalam pembinaan moral antaralain (1) Peningkatan ketaqwaan kepada Tuhan Yang Maha Esa yang mana 
dilakukan dalam kegiatan sholat wajib berjamaah, mengaji AI Quran (2) Peningkatan sikap disiplin melalui pembiasaan bersikap disiplin dalam segala hal. Setiap anak asuh diwajibkan mengikuti semua kegiatan yang terjadwal tepat waktu seperti les setiap senin sampai sabtu jam 2 Jika melanggar akan diberikan sanksi yang sifatnya mendidik, dalam artian tidak menggunakan kontak fisik, yang mana apabila anak asuh melanggar maka hukuman yang diberikan adalah anak asuh tidak diberi jajan sampai waktu tertentu, harapannya membuat mereka bisa jera, adapun sanksi lainnya yaitu membaca istigfar dan hafalan surat dalam kitab suci Al- Quran. (3) Peningkatan sikap sopan santun ini menjadi sebuah keharusan anak asuh ketika di dalam maupun di luar panti. Kesopanan anak asuh tidak hanya dalam hal tingkah laku dan tutur kata, melainkan juga dalam segi penampilan. Dalam segi penampilan terlihat bahwa anak perempuan yang tinggal di Panti diwajibkan mengenakan jilbab. (4) Penanaman sikap mandiri ini bertujuan supaya anak asuh bisa menolong diri mereka sendiri baik sekarang maupun untuk masa mendatang.

Berdasarkan hasil penelitian dibidang neurologi terbukti bahwa $50 \%$ kapasitas kecerdasan anak berbentuk pada kurun waktu empat tahun pertama sejak kelahirannya. Pada saat anak mencapai usia delapan tahun, maka perkembangan otak anak telah mencapai $80 \%$ perkembangan otak berada pada rentang pada usia tersebut.

Pada saat anak dilahirkan ia sudah dibekali tuhan dengan struktur otak yang lengkap, namun baru mencapai kematangannya pada saat setelah diluar kandungan. Bayi yang baru dilahirkan memiliki 100 miliar neuron dan berteliuran sambungan antar neouron. Memulai persaingan alami akhirnya sambungan-sambungan yang tidak atau jarang digunakan akan mengalami atrofi. Kualitas kemampuan otak dalam menyerap dan mengolah informasi tergantung dari banyaknya neuron yang membentuk unit-unit. Otak manusia bersifat hologram yang dapat mencatat, meyerap dan menglah informasi. Kemampuan otak yang dipengaruhi oleh kegiatan neuron ini bersifat spontan. Tetapi dipengaruhi oleh mutu dan frekuensi stimulasi yang diterima indra.

Kemampuan kognitif merupakan suatu yang fundamental dan yang membimbing tingkah laku anak. Kunci untuk memahami tingkah laku anak terletak pada pemahaman bagaimana pengetahuan tersebut terstruktur dalam berbagai aspeknya. Ada tiga model perkembangan 
kognitif, yaiut: model Piaget, model pemrosesan informasi, dan model kognisi sosial. Pertama model Piaget. Menurut Piaget bahwa perkembangan manusia dapat digambarkan dalam konsep funsi dan struktur. Fungsi merupakan mekansme bilogis bawaan manusia bagi setiap orang atau kecendrungan biologis untuk mengorganisasikan pengetahuan kedalam struktur kognisi, tujuan dari fungsi itu adalah menyusun struktur kognisi internal. Struktur aspek fundamental namun sangat sulit untuk dipahami secara konperensif. Piaget meyakini bahwa intelegensi bukan sesuatu yang dimiliki anak, melainkan yang dilakukan ${ }^{7}$.

Kedua, model pemrosesan informasi. Pendekatan ini merumuskan bahwa kognitif manusia sebagai suatu sistem yang terdiri atas tiga bagian: a) input: yaitu proses asimilasi dari lingkungan atau stimulasi yang masuk dalam reporter-reporter pancaindra; b) proses; yaitu pekerjaan otak untuk mentrasformasikan informasi atau stimulasi dalam cara yang beragam; dan c) outfot; yang berbentuk tingkah laku.

Ketiga, model kognisi sosial. Kognisi sosial dapat diartikan sebagai pengetahuan tentang lingkungan sosial dan hubungan interpersonal. ${ }^{9}$

\section{Kesimpulan}

Berdasarkan penelitian yang telah diadakan terhadap bagaimana Peran Pembimbing Dalam Mengatasi Perkembangan Kognitif Studi Kasus Di UPT. Panti Sosial Pengasuhan Anak Dinas Sosial Provinsi Riau dapat ditarik kesimpulan sebagai berikut:

1. Pembimbing sebagai pamong belajar, pembimbing bertanggung jawab menyediakan kegiatan belajar, melakukan motivasi terhadap anak asuh sehingga menumbuhkan partisipasi secara maksimal dalam diri anak asuh.

\footnotetext{
7 Dewi Anna Mufida, 'PEMBINAAN REMAJA DI PANTI ASUHAN AISYIYAH KABUPATEN KUDUS' (Universitas Negeri Semarang, 2013).

${ }^{8}$ AHMAD MUHLISIN, 'Pengasuhan Anak Di Panti Asuhan Yatim Piatu Al Ikhlas Kab.

Ponorogomenurutundang Undang No. 35 Tahun 2014 Tentang Perlindungan Anak' (IAIN PONOROGO, 2016).

${ }_{9}^{9}$ Ahmad Susanto, Perkembangan Anak Usia Dini Penganar Dalam Berbagai Aspeknya (Jakarta: Kencana Prenada Media, 2011).
} 
2. Pembimbing sebagai penyuluh, usaha yang dilakukan seseorang atau kelompok kepada orang lain dalam rangka memberikan informasi, penjelasan sehingga orang lain tersebut menjadi paham tentang materi yang disampaikan.

3. Pembimbing sebagai fasilitator, orang yang memberikan kesempatan kepada peserta didik atau memfasilitasi mereka sehingga mereka akan aktif mengrahkan diri sendiri.

4. Pembimbing sebagai tutor, merencanakan kegiatan pembelajaran, meaksanakan dan mengevaluasi kegiatan pembelajaran.

Hasil yang telah dicapai dalam mengatasi mengatasi perkembangan kognitif bermasalah anak tunas bangsa di UPT. Panti Sosial adalah, setiap anak asuh sudah mampu mengucapkan dan mengatakan kata demi kata. Perlahan anak asuh mulai mengenal huruf dan dapat membaca walaupun tidak begitu sempurna.

Masalah yang dihadapi pembimbing Panti Asuhan dalam mengatasi perkembangan kognitif anak asuh yaitu: kurangnya minat anak asuh, kurangnya tenaga pengajar di panti, kepribadian serta latar belakang anak asuh yang berbeda terkadang membuat para pembimbing dan pengasuh mendapat kesulitan dalam menghadapi mereka dan anak asuh yang harus selalu diperingati.

\section{Daftar Pustaka}

Anjarsari, Santi, and Sri Hartini, 'Upaya Pengelola Program Penguatan Keluarga SOS Children's Villages Indonesia Dalam Mengurangi Jumlah Anak-Anak Yang Rentan Terlantar', Comm-Edu (Community Education Journal), 1.1 (2018), 38-44

Djati, Wasisto Raharjo, 'Revivalisme Kekuatan Familisme Dalam Demokrasi: Dinasti Politik Di Aras Lokal', MASYARAKAT: Jurnal Sosiologi, 2015 <https://doi.org/10.7454/mjs.v18i2.3726>

Fitri, Anissa Nur, Agus Wahyudi Riana, and Muhammad Fedryansyah, 'Perlindungan Hak-Hak Anak Dalam Upaya Peningkatan Kesejahteraan Anak', Prosiding Penelitian Dan Pengabdian Kepada Masyarakat, 2.1 (2015) 
'Kasus-Panti-Asuhan-Polisi-Temukan -12-Anak-Dipersembunyian' Merry, Anggraini, Asrinaldi Asrinaldi, and Aidinil Zetra Zetra, 'PENGARUH KESADARAN DAN KEPERCAYAAN POLITIK TERHADAP PARTISIPASI POLITIK MASYARAKAT DHARMASRAYA PADA PILKADA 2015', Madania: Jurnal IImu-IImu Keislaman, 8.1 (2018), 109-32

Mufida, Dewi Anna, 'PEMBINAAN REMAJA DI PANTI ASUHAN AISYIYAH KABUPATEN KUDUS' (Universitas Negeri Semarang, 2013)

MUHLISIN, AHMAD, 'Pengasuhan Anak Di Panti Asuhan Yatim Piatu AI Ikhlas Kab. Ponorogomenurutundang Undang No. 35 Tahun 2014 Tentang Perlindungan Anak' (IAIN PONOROGO, 2016) QOTIMAH, LINDA KHUSNUL, 'PENGELOLAAN PANTI ASUHAN ALRIFDAH SEMARANG DALAM PEMENUHAN HAK ANAK' (Universitas Negeri Semarang, 2015)

Susanto, Ahmad, Perkembangan Anak Usia Dini Penganar Dalam Berbagai Aspeknya (Jakarta: Kencana Prenada Media, 2011) 